KALEIDOSCOPE

\author{
BALÁzs HoRvÁthY*
}

\title{
Sustainable Development and Common Commercial Policy
}

\section{Introduction}

The Treaty of Lisbon has essentially restructured the legal framework of the EU's external relations. The three-pillar system introduced by the Treaty of Maastricht has been integrated, and this unified model of the European Union made it possible to determine the Union's objectives and principles in the field of foreign actions in a uniform way. This meant at the level of the Common Commercial Policy (CCP), that the general objectives and principles of the EU external relations ${ }^{1}$ must be taken into consideration in the area of trade policy as well. Consequently the Union has to take into account not only of trade liberalisation ideas, but principles outside the conventional trade policy which include the objectives of sustainable development and environmental protection, too.

Because of these major modifications, the question arises, how the relationship of the principles of CCP to the sustainable development and environmental policy can be described. Tension between these two policy areas is understandable, because many environmental problems are related to the growing scale of global trade activity. Consequently real problem is in fact whether the sustainability ${ }^{2}$ as a principle of the EU's external relations can put a restriction on the CCP which is governed predominantly by free trade objectives.

To examine these issues in more detail, the first part of the article gives a general overview of the position of sustainable development principle in EU law as well as EU external relations (II. Sustainable development and EU external relations), after that the second main part focuses on the relationship between the sustainable development and the principles of the Common Commercial Policy in the light of the new structure of principles

* Research fellow, Institute for Legal Studies, Centre for Social Sciences, Hungarian Academy of Sciences, H-1014 Budapest, Országház u. 30; associate professor, Széchenyi István University, Deák Ferenc Faculty of Law and Political Sciences, Department of Private and Public International Law, H-9026 Györ, Egyetem tér. 1.

E-mail: bhorvathy@jog.mta.hu

This article was supported by the János Bolyai Research Scholarship of the Hungarian Academy of Sciences.

1 See Art. 21 of Treaty on the European Union (TEU).

2 The terms "sustainability" and "sustainable development" have common roots, but the "sustainability" may be used in reference to an objective or aim. On the other hand "sustainable development" is a process itself which can lead to "sustainability". This article may apply these terms in similar meaning. For detailed analysis of the terminology, see Voigt, Ch.: Sustainable Development as a Principle of International Law. Leiden, 2009. and Schwarz, P.: Sustainable Development in International Law. Non-State Actors and International Law, 5 (2005), 127-152. 
and objectives laid down by the Treaty of Lisbon (III. Principles and objectives of the Common Commercial Policy). Finally, the article is closed by concluding remarks (IV. Conclusions)

\section{Sustainable development and EU external relations}

\section{Sustainable Development in the Founding Treaties}

The following analysis does not attempt to add anything to the extent and meaning of sustainable development, but it is essential to determine the appropriate term which is connected to the objectives and principles of the Union's founding treaties.

As a matter of fact, the first reference in this regard should be the definition made by the World Commission on Environment and Development since it had a considerable influence also on the later EC formulations. The Brundtland Commission introduced in its report "Our Common Future" the term "sustainable development". According to the oftquoted definition "sustainable development" is a progress "that meets the needs of the present without compromising the ability of future generations to meet their own needs." It is commonly known fact that also the definition of report regarded the "sustainable development" as a complex phenomenon, since it referred also to the social, economic and environmental aspects of sustainable development ${ }^{4}$ expressly emphasising the struggle against poverty. ${ }^{5}$ Besides, the Brundtland Commission's term was an ethical tenet rather than a legal norm. This ethic was trans-border extended to all peoples; consequently it established a global ethical stance in relation to the global environmental problems. Moreover, this definition was a trans-temporal ethical principle knowing that it was extended across generations. ${ }^{6}$

The international debate on this issue and the preparation of the United Nations Conference on Environment and Development (UNCED) held in Rio in 1992 affected also the EC legislation; as a result, the Maastricht Treaty $(1992)^{7}$ introduced a term corresponding to "Sustainable Development" at the level of general objectives of the Community. The original EEC Treaty of 1957 specified that the Community has to promote "a harmonious

3 Our Common Future. From One Earth to One World. Report of the World Commission on Environment and Development. Parag. 27. <http://www.un-documents.net/ocf-ov.htm\#I.3> (20.09.2012).

${ }^{4}$ Ibid. "(...) The concept of sustainable development does imply limits - not absolute limits but limitations imposed by the present state of technology and social organization on environmental resources and by the ability of the biosphere to absorb the effects of human activities. But technology and social organization can be both managed and improved to make way for a new era of economic growth. (...)".

${ }^{5}$ Ibid. "(...) Poverty is not only an evil in itself, but sustainable development requires meeting the basic needs of all and extending to all the opportunity to fulfil their aspirations for a better life. A world in which poverty is endemic will always be prone to ecological and other catastrophes (...)".

${ }^{6}$ Hill, A. K. G.: Sustainable Development-An Ethical Construct in Search of a Multilateral Expression. BRIDGES between Trade and Sustainable Development, 5. (2001) 8, 13.

7 See more detailed about sustainable development in Maastricht Treaty: von Moltke, Konrad: The Maastricht Treaty and the Winnipeg Principles on Trade and Sustainable Development. International Institute for Sustainable Development, 1995. 
development of economic activities (...)" which was modified to the formula "harmonious and balanced development of economic activities, sustainable and non-inflationary growth respecting the environment". ${ }^{9}$ The Member States tried to avoid an obvious statement on "sustainable development" but the term "sustainable growth" with the emphasis of "respect for the environment" as well as the "balanced development" was a clear signal of a commitment to the sustainable development. Moreover, also the Treaty on European Union defines the objectives for the Union which included a quotation on "sustainable economic progress", a synonym of the "sustainable development". ${ }^{10}$

The Treaty of Amsterdam (1997) was not so modest as to hide the real term of "sustainable development". Accordingly the modified Treaty on European Union ensured the aim of the Member States to promote "economic and social progress for their peoples, taking into account the principle of sustainable development (...)"11 and specified as an objective that the Union has to encourage "economic and social progress and a high level of employment and to achieve balanced and sustainable development (...)."12 The Treaty establishing the European Community was amended with a similar reference to the "balanced and sustainable development of economic activities", meanwhile also "sustainable growth" remained an objective of the Community. ${ }^{13}$ In addition the most noteworthy feature of the Treaty of Amsterdam was the inclusion of principle of integration as an overarching objective of Community policies. In terms of that, the Community was obliged to integrate environmental concerns into the implementation of policies with specific regard to promoting sustainable development. ${ }^{14}$ The Treaty of Nice has not modified these clauses.

As the previous outline shows, the sustainable development is regulated in the primary sources of EU as significant objective and as a principle as well. The strongest ties were established between the sustainable development and external policies, specifically the Common Commercial Policy as a result of the principle of integration of environmental concerns. Accordingly the European Union mainstreamed sustainable development into different policy areas including also the diverse international trade relations of the Union.

\section{The impact of Sustainable Development principle on the Functioning of EU external relations}

However, doubts were expressed about the binding of these formulations, the inclusion of references to the sustainable development in the Treaties obviously had favourable effects on the EU's strategic decision-making mechanism.

8 Treaty Establishing the European Community (EEC Treaty) Art. 2.

9 EEC Treaty Art. 2 (emphasis added).

10 Treaty on European Union (as laid down by the Maastricht Treaty), Art. $3 b$.

11 See Preamble of Treaty on European Union (as amended by the Amsterdam Treaty), seventh recital.

12 Treaty on European Union (as amended by the Amsterdam Treaty), Art. B (emphasis added).

13 Treaty establishing the European Community (as amended by the Amsterdam Treaty), Art. 2 (emphasis added).

14 Treaty establishing the European Community (as amended by the Amsterdam Treaty), Art. 6: "Environmental protection requirements must be integrated into the definition and implementation of the Community policies and activities referred to in Article 3, in particular with a view to promoting sustainable development." 
Following that the European Commission made a proposal to establish an ambitious sustainable development strategy of the EU which was launched by the Member States at the Gothenburg Summit in 2001. The strategy was complementary to the Lisbon Strategy of economic and social renewal, adding a new, environmental dimension to that. The strategy proposed policy measures to overcome several unsustainable trends and set up a so-called new approach to policy-making which attempted to effectuate that the environmental, economic and social policies of EU mutually reinforced each other. In order to achieve this purpose the European Commission was obliged to submit new policy proposals to impact assessment. $^{15}$

The European Council renewed the sustainable development strategy in 2005 which set out main objectives and actions for priority-mainly environmental-areas. ${ }^{16}$ Besides in 2009, in the same year when the Treaty of Lisbon entered into force, the European Commission adopted a review of the EU's sustainable strategy and confirmed that Sustainable development remains a fundamental objective of the European Union under the Lisbon Treaty, but a number of unsustainable trends required urgent actions. In this regard, the review emphasised the need to additional efforts in the field of climate change policy, energy policy and biodiversity.

Following the EU strategic decisions making processes two concrete consequences can be highlighted from the perspective of the external policies. First, resulted from the sustainable development strategy, the Commission agreed to a policy framework for the external dimension of these questions, ${ }^{17}$ and later the Council adopted a strategy on environmental integration in the external policies. ${ }^{18}$ The strategy "Towards a global partnership for sustainable development" contextualised the sustainable development and took into consideration the position of the developing countries and the globalisation. In terms of the strategy, the priority objective of the EU was to ensure the contribution of the globalisation to sustainable development. To that end, the EU had to ensure that the developing countries are integrated equitably into the world economy as well as help them to gather the benefits of trade and investment liberalisation processes. Besides, the EU had to provide, within the framework of the external policies, incentives for environmentally and socially sustainable production and trade, and strengthen the international financial and monetary architecture and promote better and more transparent forms of financial market regulation to reduce global financial volatility and abuses of the system. ${ }^{19}$ The sustainable management of natural and environmental resources was also a substantive priority of the strategy which covered also an ambitious aim to reverse effectively the current trends in the loss of environmental resources at national and global levels by 2015. The strategy also laid

15 A Sustainable Europe for a Better World: A European Union Strategy for Sustainable Development. (15.5.2001). COM(2001) 264 final.

${ }^{16}$ Climate change and clean energy; sustainable transport, sustainable consumption \& production; conservation and management of natural resources; public health; social inclusion; demography and migration; global poverty and sustainable development challenges. See Review of the Sustainable Development Strategy-A platform for action. (13.12.2005), COM (2005) 658 final.

17 Koutrakos, P.: Legal Basis and Delimitation of Competence in EU External Relations. In: Cremona, M.-de Witte, B. (eds): EU Foreign Relations Law. Constitutional Fundamentals. 2008. 76.

18 Towards a global partnership for sustainable development (13.2.2002), COM(2002) 82 final.

19 Ibid. 3.1. The last objective is strangely interesting from the perspective of the actual financial crisis. 
down objectives concerning the poverty and social development, the coherence between policies, better governance and financing the sustainable development.

The second consequence of the strategic decision was the setting up of the system of Sustainability Impacts Assessments (SIAs). Since 2001, the European Commission carries out impacts assessments of all trade agreements between third countries and the EU with external consultants. The assessment aims at identifying potential positive and adverse effects on sustainable development. The methodology is based on individual sustainability indicators in order to measure the impact that further liberalisation and changes in rulemaking might have on sustainability. The indicators are balanced between economic, environmental and social fields. ${ }^{20}$

\section{Principles and objectives of the Common Commercial Policy}

\section{The reform of the Treaty of Lisbon}

The objectives and principles of the CCP before the Treaty of Lisbon were laid down in a homogeneous, consistent and relatively closed structure. This consistency was based primarily, as a leading principle, on the liberalisation, which allowed the legal and political framework of the Common Commercial Policy to develop according to the own logic in line with its free trade commitments to the international economic law and the legal order of WTO. However, the expansion of the external policy horizon of the European Communities and the introduction of new policy areas led to conflicts of objectives more frequently, causing tensions between the CCP and other external policy areas. Significant examples were the introduction of the Common Foreign and Security Policy, and the horizontal principle of integration in the field of the environment policy, which was indicated above.

The main actors, the European Commission as well as the Council were trying always to meet these "external" requirements, e.g. by means of the integration of sustainability principle into the trade policy or inclusion of foreign policy and human rights clauses in the bilateral trade agreements, but there were no clear Treaty provisions governing the relationship the internal principles of the Common Commercial Policy and these external principles and objectives dependent on other policy areas.

As a result of the Treaty of Lisbon, the Common Commercial Policy has become an integral part of the Union's external action. The Treaty on European Union (TEU) and the Treaty on the Functioning of the European Union (TFEU) have made it clear that the EU has to ensure consistency between the different areas of its external action and pursue and implement the general principles and objectives in the whole field of the EU external relations. Consequently the $\mathrm{CCP}$ is founded on a two-level structure of principles and objectives which encompasses not only inner principles like as the liberalisation but also the peripheral principles outside the trade policy including the sustainable development as well. In the following section this twofold structure-both internal and external fields-of principles are briefly considered.

20 Trade and Environment. European Commission, Brussels, 2006. 7. < http://ec.europa.eu/ environment/integration/pdf/trade_envt.pdf >. (20.9.2012.). More detailed: Handbook for Trade Sustainability Impact Assessment. Brussels, 2006. 


\section{Internal principles of CCP: Trade liberalisation and uniformity}

In context with the internal principles of the Common Commercial Policy first should mention the characteristics and the importance of the principle of liberalisation and the principle of uniformity.

The liberalisation principle was already inserted in Art. 110 EEC Treaty, and its extent was well shaped through the jurisprudence of the European Court of Justice (ECJ) quite early. ${ }^{21}$ However, the ECJ stated that the principle of liberalisation did not establish "unlimited" duty to remove all trade barriers in relation to other trading partners. In other words, protective trade measures can be justified by other objectives of the Treaty, e.g. by reason of environmental considerations.

The principle of liberalisation has remained mutatis mutandis in the Treaty of Lisbon incorporated in the new Art. 206 TFEU. In terms of that, the Union has to contribute in the common interest, to the harmonious development of world trade, the progressive abolition of restrictions on international trade and foreign direct investment and the lowering of customs barriers and other barriers. ${ }^{22}$ Comparing to the text of the Treaty of Nice, the wording of Art. 206 TFEU seems to be not only technically modified but formulated much stricter and more categorical. In accordance with the previous formulation in Art. 131 TEC, ${ }^{23}$ the Member States "only" aimed to contribute to the progressive abolition of restrictions on international trade and the lowering of customs barriers, and in contrast, the expression of Art. 206 TFEU emphasizes in a more definitive form that the EU "shall contribute" to that. Besides it cannot be passed over that the reference to the "competitive strength of undertakings" in former Art. 131 TEC has disappeared from the modified Treaty text. It can be assumed that repeal of this paragraph does not mean substantial change; therefore it only has symbolic significance. It may indicate only that the emphasis on tariff elimination among the Member States, as well as its impact on the competitiveness is already obsolete today, contrary to the zeitgeist of the 1950s, when the Rome Treaty, as well as the previous formulation of the article were composed. That time the Member States needed strong arguments for the liberalisation programme in the internal market.

The principle of uniformity remains also an element of the Common Commercial Policy, such as Art. 207 TFEU Section 1 shows that trade policy shall be based on "uniform principles." It can be interpreted as a requirement for the customs union, seeing that customs union and the internal market would be ineffective without the adequate, uniform regulation. In addition to that it is necessary to note that according to the case law of the ECJ, the uniformity principle concerns only the internal relations of the EU, consequently, a

21 See the following leading cases: 5/73, Balkan, ECR 1973, 1091.; 112/80, Dürbeck, ECR 1981, 1095.

22 Article 206 TFEU (ex Article 131 TEC): "By establishing a customs union in accordance with Articles 28 to 32, the Union shall contribute, in the common interest, to the harmonious development of world trade, the progressive abolition of restrictions on international trade and on foreign direct investment, and the lowering of customs and other barriers."

23 Article 131 TEC (as amended by the Treaty of Nice): "By establishing a customs union between themselves Member States aim to contribute, in the common interest, to the harmonious development of world trade, the progressive abolition of restrictions on international trade and the lowering of customs barriers. The Common Commercial Policy shall take into account the favourable effect which the abolition of customs duties between Member States may have on the increase in the competitive strength of undertakings in those States." 
commitment to comply with external obligations such as an equal treatment of third states, non-discrimination or most favoured nations principle cannot be derived from this Treaty provision. ${ }^{24}$ On the other hand, the principle of uniformity has also helped the ECJ to interpret the scope of exclusive competence character of the CCP. In this regard, the principle could play a crucial role also in the future, because the Treaty of Lisbon extended the limits of competence of the trade policy, but as highlighted above, the principle is inadequate to establish the incompatibility of the EU law with international regulations, e.g. obligations arising from multilateral environmental or trade agreements.

\section{External principles of the Common Commercial Policy}

As noted in the introduction of this article, the Treaty of Lisbon-as a remarkable innovationlinked the internal objectives and principles of trade policy to the general principles of EU's external relations. In terms of Art. 205 TFEU, the Union's action on the international stageincluding the Common Commercial Policy-has to be based on principles, guided by the objectives and conducted in line with the general provisions of the Treaty. ${ }^{25}$ In other words, the internal principles of CCP driven by the free trade concerns are not isolated anymore and as a result of the concept of uniform foreign relations introduced by the Treaty of Lisbon, also the general principles and objectives must be taken into consideration. These general principles and objectives are laid down in Art. $21 \mathrm{TEU},{ }^{26}$ which includes approaches e.g. to the human rights, solidarity, freedom and equitable (fair) trade, principles of international law, ${ }^{27}$ and the most important from the current perspective is that the sustainability and the protection of the environment are incorporated, too. Art. 21 Para. 2 subpara. f) emphasises that the EU, working for a high degree of cooperation in international relations, helps develop international measures to preserve and improve the quality of the environment and the sustainable management of global natural resources, in order to ensure sustainable development.

This language of the principle does not explain the extent of the term "sustainable development", but it is clear that the sustainable development in this formulation puts the emphasis on the environmental aspects. The term "international measures" is questionable because it can be interpreted in two ways. Its first reading could be that the "international measures" encompasses only cooperative, i.e. bi- or multilateral instruments which are suitable for ensuring the sustainable development. Although the article refers to the "a high degree of cooperation in all fields of international relations", this interpretation would quite restrict the scope of Union's external action. Consequently, my view is that the term "international measures" could be interpreted in a wider sense, specifically it can cover beyond the bilateral and multilateral measures also the unilateral actions of the EU (e.g. restrictions, taxes for environmental purposes etc.). Hypothetically speaking, it does not mean anyway that the article would provide reasons for justification of measures contravening international law, but its second interpretation would not disregard the

24 See 52/81, Faust/Commission, ECR 1982, 3745.

25 Article 205 TFEU: "The Union's action on the international scene, pursuant to this Part, shall be guided by the principles, pursue the objectives and be conducted in accordance with the general provisions laid down in Chapter 1 of Title V of the Treaty on European Union."

${ }^{26}$ Cf. with Art. 21 TEU Paras 1 and 2.

27 See commentary for the principles: Grabitz, E.-Hilf, M.-Nettesheim, M.: Das Recht der Europäischen Union. München, 2011. (via Beck-Online). Art. 21 EUV side-note 1. 
possibility of taking unilateral actions in order to ensure sustainable development in advance.

Moreover, the sustainable development principle appears in another context, too. According to subparagraph d) the EU foster the sustainable economic, social and environmental development of developing countries with the primary aim of eradicating poverty. However, this formulation differs from the sustainable development principle in subparagraph f). On the one hand, this conception of sustainable development seems to be much wider, because not only the environmental but also the economic and social dimensions are referred. Second, it focuses on the social aspects, to be more precise, the accent is put on the fight against poverty. Third, this quotation is applied only to the relations established with the development countries; consequently the scope of this objective is restricted to a specific area of the Union's external action.

Even if this listing is not new, ${ }^{28}$ but the relevance of these principles is recognized in the field of CCP first time in the history of EU law. Consequently, the Treaty reform made an important contribution to helping ECJ to determine the relationship between the internal principles and external principles, in particular the human rights clauses, social standards, environmental concerns from entirely new perspectives.

\section{The relationship between the inner and external principles of CCP - Possible conflict areas}

Following the strict consistency prescribed by the Treaty, the compliance of the internal and the external principles are required. For this purpose, the European Union has to ensure consistency between the different areas of its external action and between these and its other policies. The consistency requirement is reinforced by institutional cooperation as well, it obliges also the key players of external action. In other terms the Council and the Commission, assisted by the High Representative for Foreign Affairs and Security Policy, who have to cooperate in order to ensure this consistency. ${ }^{29}$ The consistency requirement is still handled more clearly on the level of the Common Commercial Policy (and other external policies laid down in the TFEU) ${ }^{30}$ because the provisions of Art. 21 on consistency, as indicated above, is repeated in Art. 205 TFEU. ${ }^{31}$ In addition, the binding to the principles and objectives of Union's external action is stressed-unnecessarily again-in the Art. 207 TFEU. ${ }^{32}$

According to the grammatical and systematic interpretation of these provisions it is unquestionable that the inherent principles and objectives of CCP mostly governed by free trade ideas are already subordinate to the general principles of external relations, including the sustainable development. As a result, the Treaty of Lisbon affords chance for a well-

28 Article 11 TEU. Cf. with ex-Art. 11 TEU Para. 1. (As amended by the Treaty of Nice).

29 Article 21 Para. 3 TEU.

${ }^{30}$ See in TFEU Part Five: The Union's External Action. Title I: General Provisions on the Union's External Action.

31 Cf. with Art. 205 TFEU.

32 Article 207 TFEU Para. 2: "The common commercial policy shall be conducted in the context of the principles and objectives of the Union's external action." 
built harmony between the trade interests and other, external social policy concerns, ${ }^{33}$ which can pave a way for establishing a value-oriented Common Commercial Policy.

If several principles and objectives are incorporated in a systematic order, the question concerning the potential conflicts between the different areas, principles and objectives are always arisen. This issue is specifically relevant in this case because the Treaty of Lisbon has inserted several principles and objectives which could be hardly reconciled with the logic of Common Commercial Policy and principally with the liberalization principle. Therefore, the expected conflict touches upon the trade and environment debate, which has importance not only at the level of the European Union, but also in the field of international trade, namely the World Trade Organization. The core argument of the debate focuses on the indisputable knowledge that the abolition of trade barriers may not have only beneficial impacts. However, the damaging effects caused by the liberalisation most often come up not in the field of trade but the areas of other social dimensions like as social policy or the environment.

This conflict potential is less concentrated at the level of the European Union than on the international field. It is because the EU, as indicated earlier, was always a dominant promoter of the environmental issues, and the introduction of the horizontal environmental integration principle by the Treaty of Amsterdam required itself a solution of the conflict between the environmental and trade policies of the European Union. However, there is a significant difference between the impact of the horizontal integrative clause and the new hierarchy of principles introduced by the Treaty of Lisbon. The idea of the present Art. 6 of TFEU ("Environmental protection requirements must be integrated into the definition and implementation of the Community policies and activities [...] in particular with a view to promoting sustainable development") is established on a coordinated, parallel-like relation between the environmental and trade concerns. Practically, such integration is always depending on the "substance" in which it should be incorporated. In other words, the integrated point of the environment can have different impacts on the different policy areas. Contrary to that, the relationship between the environmental concerns and the CCP based on the new principle structure introduced by the Treaty of Lisbon is not a coordinative but a hierarchical relation. A hierarchy is a strict structure in this sense which cannot allow "trade-offs" or extensive balancing between the interest of the conflicting areas. As a result, according to this hierarchy no measures can be adopted within the CCP which is detrimental to the sustainable development and sustainability, i.e. negative effects on the environment can not be compensated by the benefit resulted from the trade liberalisation.

Following these considerations and due to the coherence requirement of the Treaty, the objective and principle structure allows solving the conflicts between the abolition of trade barriers and the environmental concerns, including the sustainable development principle.

It does not mean anyway, that the possible conflicts between trade and environment are conceptually excluded. At the Union's level, institutional conflicts can be presumed. The European Parliament can be regarded as an area of conflict, since it has already made clear that the Union has to involve non-economic, sociopolitical approaches closely in its external action. Moreover, also the Union's High Representative for Foreign and Security

${ }^{33}$ Contrary, the "politisation" of CCP is harshly criticised by e.g. Tietje, see Tietje, Ch.: Die Außenwirtschaftsverfassung der EU nach dem Vertrag von Lissabon. Beitrage zum Internationalen Wirtschaftsrecht. Heft 83. January 2009. 20. 
Policy has potentially to face tension, because she must solve the controversy between the Member States, Council and Commission.

It seems rather difficult to represent the external objectives and principles of the EU, including the related environmental concerns at the level of the World Trade Organization. In other words, what from the viewpoint of consistency of the EU external actions can be positively evaluated, it can be regarded as a "threat" from the site of the WTO and its trade liberalisation based principles. The question is how the environmental consideration and e.g. human rights, or social objectives can be brought into line with exceptions of the GATT-WTO legal order (e.g. GATT Article XX). An example for that could be a more recent disputed area within the WTO. The relationship between the law of the WTO and the multilateral environmental agreements which are encompassing also trade measures is actually a topic with high importance. ${ }^{34}$ Regarding that, the EU as a strong environmental promoter, represents the concept of the supremacy of the multilateral environmental agreements over the WTO law, consequently the position of the EU is to hinder the legal possibility of review of these trade measures under the WTO dispute settlement rules. The EU's position in this example can be regarded as a result stemming from the strong environmental consciousness of the Common Commercial Policy. In other words, the concept of the CCP which is subordinated to the sustainable development fundamentally differs from the idea of the World Trade Organization, ${ }^{35}$ which means a real conflict potential. However, it is a conflict, but not an antagonism, because it can be regarded also as an opportunity. Since the EU, the leading actor and demandeur for environmental issues can have a beneficial influence on trade and environment debate within the World Trade Organization in order to build up a framework which substantially integrates the concerns of sustainable development into the international trade law.

\section{Conclusions}

The present article has showed that following the Treaty of Lisbon, the Common Commercial Policy (CCP) became subordinate to the general principles and objectives of the EU's external actions. These principles embrace also the environmental concerns, namely the sustainable development and protection of the environment.

${ }^{34}$ See for the details, Vogel, D.: Trade and Environment in the Global Economy: Contrasting European and American Perspectives. In: Vig, N.-Faure, M. (eds): Green Giants? Environmental Policy of the United States and the European Union. 2004. 231-252; and Baker, S.-McCormick, J.: Sustainable Development: Comparative Understandings and Responses. In: Vig-Faure (eds.): Green Giants? Environmental Policy... op. cit. 277-302.

35 Even though the WTO Agreement contains reference to sustainable development, but this preambular language is much restricted, see Voigt, supra note, 127-130. Despite of that, some authors are arguing that the sustainable development principle is incorporated also ideologically in the WTO structure, see for instance, Hartwick, E.-Peet, R.: Neoliberalism and Nature: The Case of the WTO. Annals of the American Academy of Political and Social Science. Vol. 590, Rethinking Sustainable Development (Nov., 2003), 188-211. Generally for the environmental background of the GATT and WTO agreements: Macmillan, F.: WTO and the Environment. London, 2001; Rao, P. K.: The World Trade Organization and the Environment. London, 2000; Charnovitz, S.: A New WTO Paradigm for Trade and the Environment. Singapore Year Book of International Law, (2007) 11; Charnovitz, S.: The WTO's Environmental Progress. Journal of International Economic Law, 10 (3) 2007. August. 
As indicated above, the EU may have to face a twofold conflict in this regard. The sustainability must be reconciled with other objectives of the CCP, but the hierarchy between the sustainability and other goals of the EU can make definite solutions to the supposable conflicts. Also, the possible institutional tensions can be handled thus; the conflict potential should not be overestimated for the reason that the rules of the Treaty became clearer. In addition, it is hoping that the ECJ's interpretation will add much more to this relationship and meaning of sustainable development in this regard.

Moreover, the integration of sustainability in the trade policy of European Union presumably will lead to conflicts to be solved on the international level, e.g. within the World Trade Organization. Although the current agenda of the Doha Round includes also issues on "trade and environment", but it has not yet resulted in any agreement on that problems (nor on other subject, because properly speaking, the negotiations are inactive actually). If the negotiations get going again, the real question at stake would be how the EU could shape the debate in order to reach an agreement on trade and environmental issues. In this sense, the sustainability objective should not be regarded as a "conflict causer" but an opportunity to carry the environmentally conscious trade policy into effect not only in the EU's but also in multilateral level. 